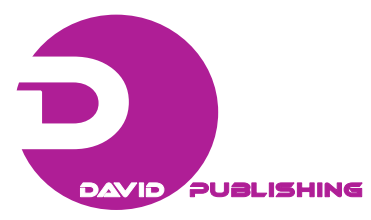

\title{
Stresses Analysis on a Rail Part
}

Cassio Eduardo Lima de Paiva ${ }^{1}$, José Luíz Antunes de Oliveira e Sousa ${ }^{1}$, Luiz Carlos de Almeida ${ }^{1}$, Paulo Roberto Aguiar $^{1}$, Luiz Fernando de Melo Correia ${ }^{1}$, Juliana Silva Watanabe ${ }^{1}$, Rodrigo Moreira de Carvalho ${ }^{1}$, Creso de Franco Peixoto ${ }^{1,2}$ and Denis Palomo Paschoalin ${ }^{3}$

1. Geotecnical and Ttransportation Department \& Department of Structure, School of Civil Engineering, University of Campinas, Campinas 13083-852, Brazil

2. Ignatian Educational Foundation, São Bernardo do Campo 09850-901, Brazil

3. VALE S. A., Belo Horizonte 30140-001, Brazil

\begin{abstract}
The EFVM (Vitoria Minas Railroad) is one of the main railways in Brazil. It transports freight trains of ore, 220 wagons each. These wagons have 2 boogies of 2 axles each and 32 metric tons on metre gauge. Elastic strains were measured on a special part of this railway due to these trains. The main load to evaluate stresses and strains was a G 16 Locomotive, a C-C kind from Vale, a Brazilian Company. The measurements were obtained by dynamic deflectometer installed on a main line of this railway, near Ipatinga, a city from Minas Gerais, one of Brazil states. This track was equipped to obtain stresses under an equal repeated static load. A simulation of the stresses was made under critical strain by Ferrovia 1.0 software. It was also made an evaluation of unequal results from neighbor sleepers taking in comparison two equipped parts of this railway, one with compacted ballast and no compaction to the other. The results were strain limited, avoiding breakage or damage to the studied rails. This work analyses these measurements focusing on the improvement of track quality.
\end{abstract}

Key words: Railway track, field strain survey, rail stresses.

\section{Introduction}

Nowadays, the Brazilian railway loads have increased constantly, even when the very high rate goes to road transportation, practically carrying almost all Brazilian passengers and the major part of loads.

One of the main reasons that led to the reduction or canceling of Brazilian long journey passenger trains is the high traffic volume accumulated over the years on lines sub-maintained to those practically abandoned ones. As dealers revenue have not reached sufficient amount for adequate track maintenance, it was decided the cancellation of passenger services. In this case, canceling passenger services, the operational speed was reduced, minimizing rail failure risk by means of the reduction of dynamic impact coefficient. In this case, to balance the productivity, the reduction

Corresponding author: Cassio Eduardo Lima de Paiva, professor, research field: transportation infrastructure. E-mail: celpaiva@fec.unicamp.br. of speed was counterbalanced with the increase of longer trains.

This abandon state of passenger services was due to some special features of Brazilian railway privatization program, ran late $1990 \mathrm{~s}$. At that time almost all Brazilian railways belonged to the government. The absence of adequate level of resources from federal budget to keep them running, pushed the government to start a concession program. Besides the concession granted 50 years to each enterprise, that could be thought as a very large period of concession, this length of time would not guarantee money for a wide operation of passenger and load trains, because the high level of worn rails and rotten sleepers would require an excessive amount of financial resources. If the dealers decided to continue passenger services they needed to spend money that could jeopardize the financial balance of its business. This long period of concession, fifty years, could be thought as a kind of sale, not an effective concession, 
to reduce government costs. The adequate length of time permits government and dealer to evaluate the business, to know if the service quality reached the expected level and if the profit would be fair to social and economical approaches.

In order to optimize the growing transportation volume, mainly concerning to ore, it was necessary to settle new railway maintenance procedures. The constant increase of traffic railway demands detailed analyses on all Brazilian railways, from platform bearing capacity to sleepers and rails lifetime. In this maintenance scenario, rails stresses and strains are the most important study, to guarantee transportation continuous service and to keep enough capacity to attend the growing demand. The new decision-making was conceived to guide Brazilian railway maintenance processes, which is a group of procedures and techniques program as a director plan. To apply this group of procedures, technicians selected parts of EFVM, a metric gauge railway that crosses Minas Gerais, one of the largest States of Brazil. In two lines of EFVM, deflection measurements were taken and the results were analyzed. In these railway parts, the rails are fixed on steel sleepers. The main study was to analyze rail stresses and strains from each studied railway part. The principal difference between them was ballast tamping levels.

Each studied railway part received a special name. The line part named Case A presents a non tamped ballast. In this line, repetition measurements were very common. It was needed to remake the work always that the high vibration and elevated deflections generated non reliable group of values. The wide deflection on its sleepers became difficult for evaluations. The work on the other line, adequately tamped, named Case B, occurred without any difficulty. Probably the higher ballast stiffness helped to avoid excessive vibration and wide deflection amplitude to the sleeper.

The estimated stresses related to the Case A were calculated considering sleepers under double spacing, because it was significant the amount of sleepers that did not show effective contact between bottom of rail base and sleeper top. This criterion was adopted to reduce the error between estimated and real stresses.

The priorities during the field measurements held reliable data and, as much as possible, a significant amount of values. Nevertheless, all measurements that did not present good quality or adequate results were discarded. For data acceptance or discharging decision, it was used excessive vibration or wide sleeper deflection as the main tools. Therefore, it could be done the comparison of estimated and calculated stresses, related to measured deflections and calculated values by elastic models, respectively. The deflections data were obtained by means of strain gauges adhered to the rails.

\section{Rail Deflections Caused by Loading}

The measurements were taken at several parts of EFVM near Ipatinga, a city between Belo Horizonte and Vitoria, Capitals of Minas Gerais and Espirito Santo States, respectively. Its traffic is composed by heavy hall and passenger trains. This line is one of two long journey passenger trains offered today in Brazil. The main features of this railway at these studied places are shown in Table 1 .

According to Table 1, the profile of features of this studied railway part, can be considered as a representative one to the Brazilian railways. The TR 68 , a Brazilian rail standard equivalent to $136 \mathrm{RE}$ is commonly applied to lines under high traffic, mainly for those of ore trains. The Deenik rail fastening, an elastic one, is also very applied for long extension of rails all over the country. But, the steel sleeper of this studied railway is not very common. The wooden sleeper is the most common on Brazilian railways, mainly from reforested eucalyptus wood, because it is the cheapest Brazilian sleeper, despite its low capacity to permit higher speeds. Nevertheless, it was decided to evaluate this railway as a representative one, because its traffic has also passenger trains, a profile 
Table 1 Main features of the studied railway parts at EFVM.

\begin{tabular}{|c|c|c|}
\hline Element or feature & Kind & Main characteristics \\
\hline Rails & $\begin{array}{l}\text { TR-68 (136 RE) } \\
\text { (Brazilian rail standard) }\end{array}$ & $\begin{array}{l}\text { Brazilian rail standard is equivalent to the pattern } 136 \text { AREMA (America railway } \\
\text { engineering maintenance) }\end{array}$ \\
\hline Rail fastening & Deenik & Elastic rail fastening \\
\hline Sleepers & UIC-865 & $\begin{array}{l}\text { Steel sleepers: } 2.20 \mathrm{~m} \text { length, } 0.23 \mathrm{~m} \text { width and } 0.09 \mathrm{~m} \text { height, } 12 \mathrm{~mm} \text { minimum } \\
\text { thickness on the surface, } 600 \mathrm{~mm} \text { spacing }\end{array}$ \\
\hline Gauge & Metric & $1,000 \mathrm{~mm}$ \\
\hline Ballast & Crushed stone & Thickness $0.39 \mathrm{~m}$, grading curve correction \\
\hline
\end{tabular}

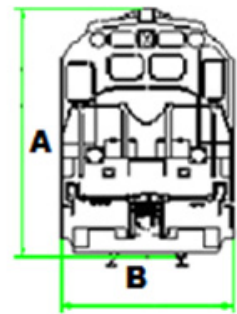

Front view

\begin{tabular}{|l|c|}
\hline Dimensions & Length $(\mathrm{m})$ \\
\hline A & 4.55 \\
\hline B & 2.76 \\
\hline C & 3.53 \\
\hline D & 1.59 \\
\hline E & 10.42 \\
\hline F & 18.65 \\
\hline G & 1.91 \\
\hline H & 0.08 \\
\hline I & 3.54 \\
\hline J & 0.75 \\
\hline
\end{tabular}

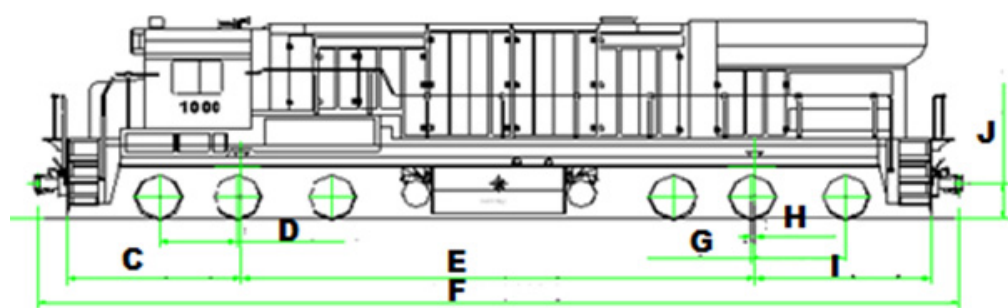

Narrow gauge: $1,000 \mathrm{~mm}$

side view

Fig. 1 Schematic views of G 16 locomotive—bogies and axles of G 16 (C 30 M 3) [1].

Table 2 G 16 (C 30 M 3) locomotive-main features [1].

\begin{tabular}{ll}
\hline Traction kind & Electro-diesel \\
\hline Builder & GE (general electric) \\
Wheel arrangement & C-C kind \\
Power output & $3,000 \mathrm{HP}$ \\
Wheel diameter & $914.4 \mathrm{~mm}$ \\
Total weight & $1,253,670 \mathrm{kN}(125,367 \mathrm{kgf})$ \\
Load per axle & 209,000 to $220,000 \mathrm{kN}(20,900$ to \\
\hline
\end{tabular}

of usage that is very important to be reestablished on the Brazilian scenario, under strong social importance approach. The metric gage is the most common all over the country. The most common Brazilian rock formations to get crushed stone for ballast are composed by diabase, basalt, granite, gneiss or limestone, which require particle size distribution correction (grading curve correction) among other procedures to meet high load capacity and good drainage [2].

The rails of these two selected railway parts are TR-68 (136 RE), the heaviest Brazilian standard. They are fastened on steel sleepers. In each of these studied parts were installed 12 gauges in different parts of the rail, to measure deflections generated by the traffic of the pattern locomotive, the GE C $30 \mathrm{M}-3$, named G16 VALE [1]. The studied locomotive, a C-C kind, has a gap of $1.680 \mathrm{~mm}$ between first and second axles and $2.020 \mathrm{~mm}$ between the second and third axles.

The general layout of this locomotive is shown in Fig. 1 and its main features are shown in Table 2. 
The railway reaction to the locomotive movement was evaluated by elastic deflection, which was measured by two laser deflectometers installed in each selected sleeper for measurements [3]. In each sleeper selected, one is on the sleeper tip and the other, on the ballast level, next to the sleeper. This procedure allowed for strain basin design from the entire locomotive shape, as shown in Fig. 2. The applied field procedure approached a specific and repetitive way to install the apparatus in each research site, considering gauges, computer and connectors. This adopted procedure was conceived to avoid measurement differences generated by possible divergences from received frequencies that could generate inacceptable results.

For each pair of measurements, during rail evaluation, the track and ballast elasticity modulus was estimated, according to a retro-analysis model. In Case A, the spatial twist on the sleepers, a common movement generated by load application differences on each rail of the studied sleeper, causes deflection measurement losses. When this occurs, the laser emission does not return to the signal receptor, losing data. This problem was common when using laser deflectometers for line strain measurements. In Case $B$, the deflection values permitted to build the deflection basin shown in Fig. 2.

The retro-analysis procedure considered the system charged with the load amplitude and geometry of the studied locomotive and also the track features. From the deflection measurements, it was determined the Winkler coefficient applied to the Case B, equals to $0.6 \mathrm{~N} / \mathrm{mm}^{3}\left(6 \mathrm{kgf} / \mathrm{cm}^{3}\right)$.

The adopted Winkler coefficient was considered adequate for railways working under good level of maintenance. According to Eisenmamm, values between $0.5 \mathrm{~N} / \mathrm{mm}^{3}\left(5 \mathrm{kgf} / \mathrm{cm}^{3}\right)$ and $1.0 \mathrm{~N} / \mathrm{mm}^{3}(10$ $\mathrm{kgf} / \mathrm{cm}^{3}$ ) are considered as, respectively, "good condition of maintenance" and "very good condition of maintenance" [4].

In the two studied parts, Case A and Case B, six rail gauges were installed in each rail [5]. Two of them were fixed at the middle of sleepers spacing, i.e., in the middle of the rail part length between two sleepers support. In this situation, one gauge was stuck on the head side, i.e., on the side surface of the head and the

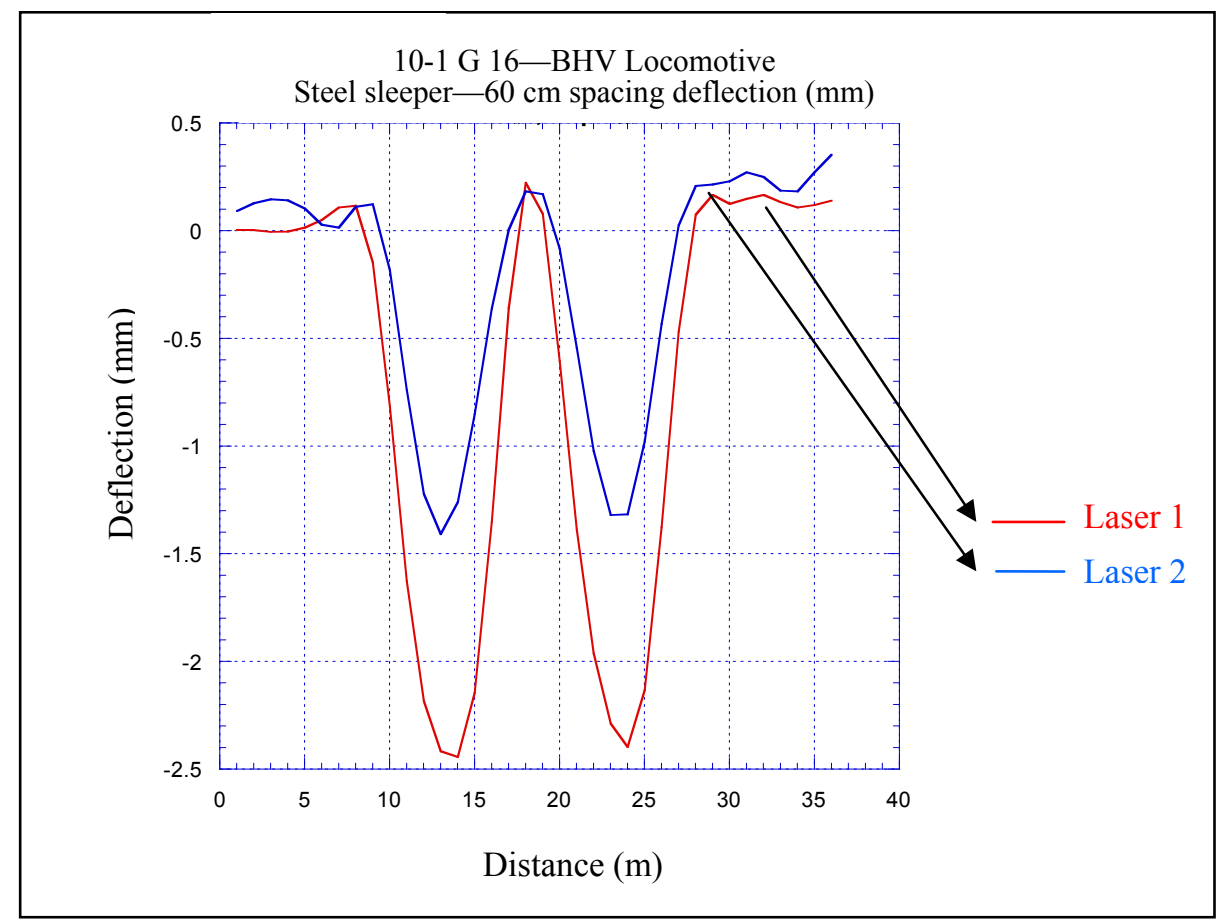

Fig. 2 Deflection basin-Case B. 
other on the superior face of base rail. In this case, it was expected to estimate the maximum force moment. The other four gauges were positioned near sleeper support, stuck on the rail the same way as the previous ones, as presented at the B-B and C-C cross section in Fig. 3. Therefore, the estimated stress was related to the highest sheer force. Fig. 4 shows rails and electrical devices, where it is easy to see these considered dots before, places that were installed gauges and its connectors. In this picture, the wires are shown going to the right direction, from each studied gauge. According to Fig. 3, the gauges were named as Strain 0 and Strain 1 at central section, Strains 2 to 5 near the sleeper support, Strain 2 and 3 to the left and Strains 4 and 5 to the right.

To the data field acquisition, it was used an equipment model SCXI-1001 from national instruments, with a computer caption card type SCXI-1521B for deflections acquisition, receiving data from electric gauges considering Wheatstone Bridge Theory. The data acquisition program was done in LabView and stored in a notebook [6].

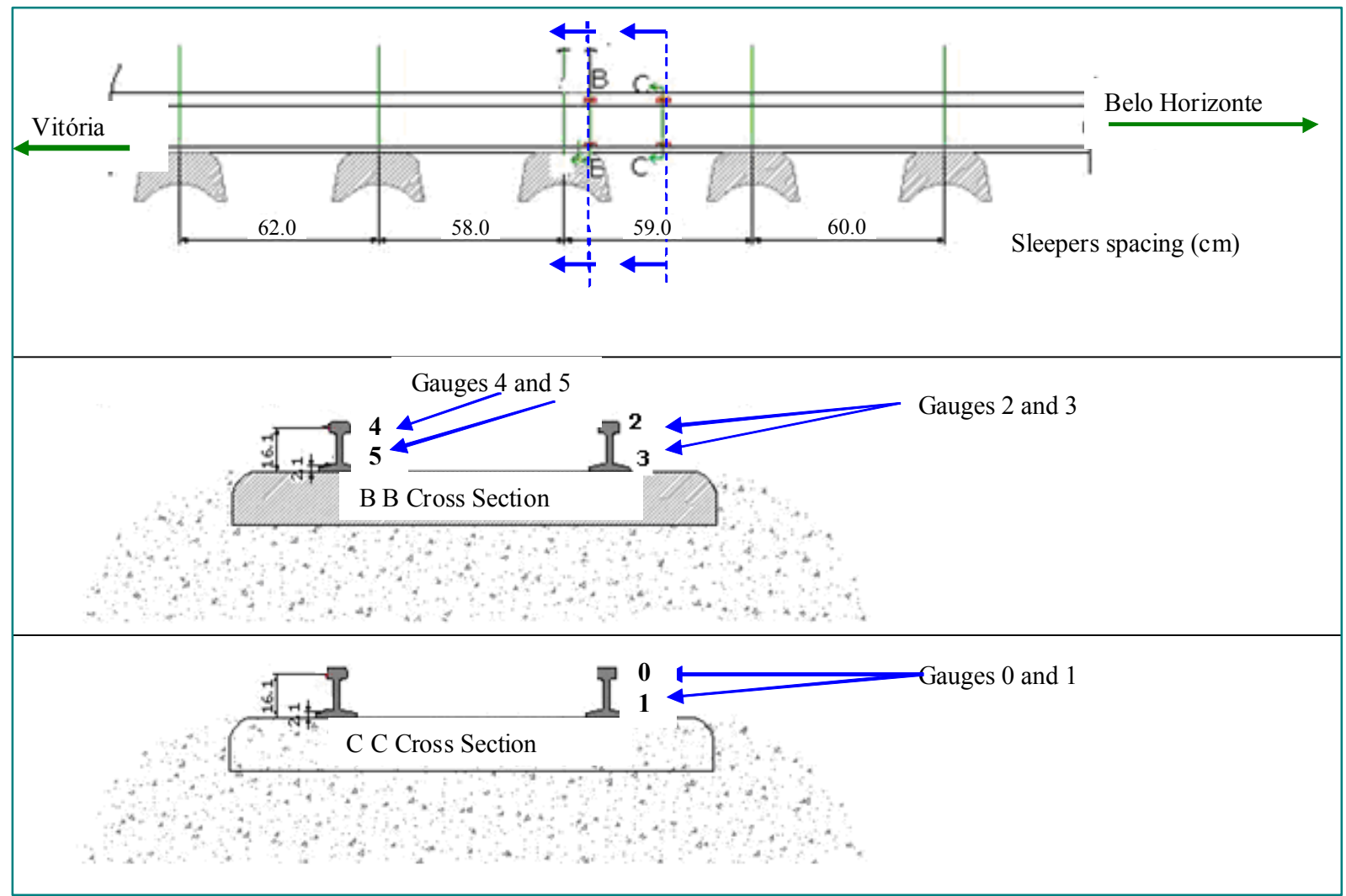

Fig. 3 Gauges distribution in relation of rails and sleepers.

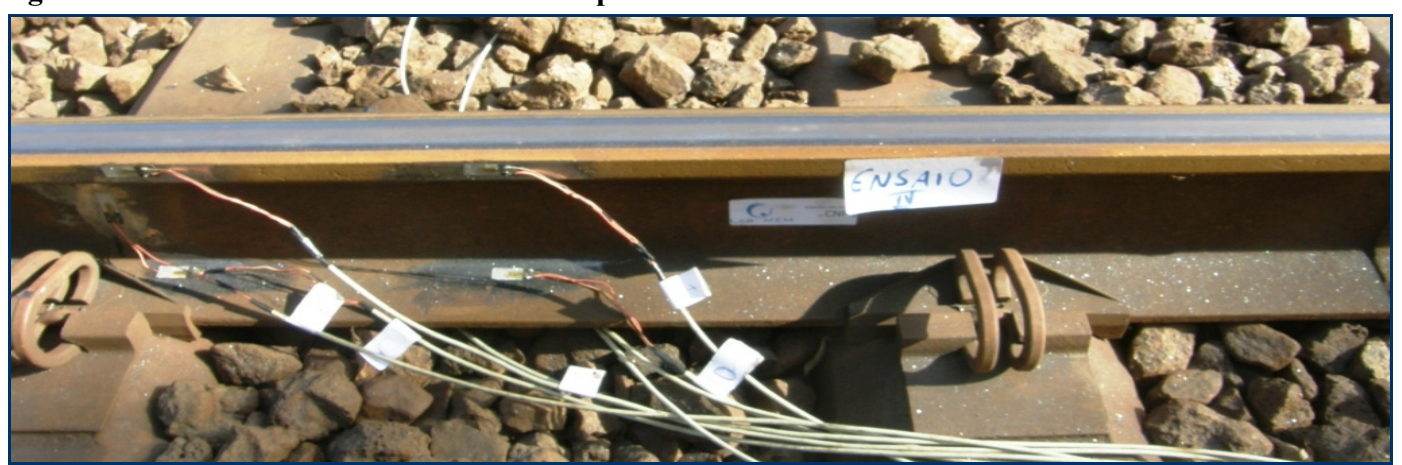

Fig. 4 Electrical devices on the rail side (Case $A$ and Case B). 

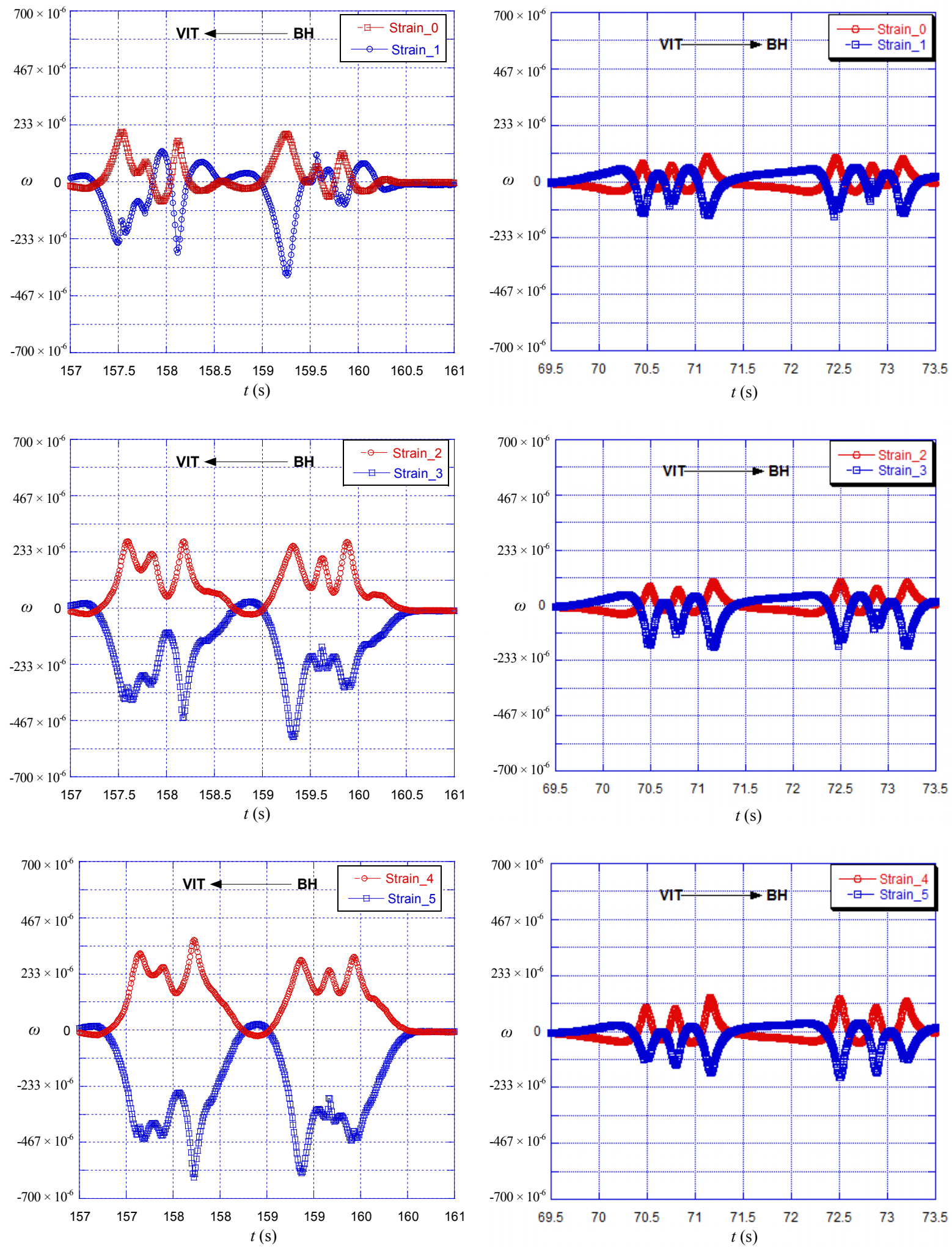

Case A

Case B

Fig. 5 Longitudinal deflection graphs of six rail parts (Case A: left column; Case B: right column). Units: abscissas-time in seconds (s); ordinates-specific deflection $\left(10^{-6} \mathrm{~m} / \mathrm{m}\right)$. 
The Gauges 4 and 5 were installed in an equivalent way of Gauges 2 and 3, but inside the other rail, as shown in Fig. 3.

Fig. 5 shows the graphs of strain versus time [7]. These data were obtained from the six mentioned gauges of Fig. 3, during G 16 locomotive passage, loading and unloading the rails. The graphs on the left column of Fig. 5 are applied to Case A and the graphs of right column, to the Case B. Fig. 5 shows strains which are influenced from the period of charge, which means the time between each locomotive axle passing at this studied point.

In Fig. 5, the high amplitude of deflections shown on the left column, Case A related, compared to the amplitude deflections shown on the right column, Case $B$ related, could be explained in relation of tamping differences. The support rail deficiency of the Case A line, observed during locomotive passage, depends strongly to the adequate tamping absence and to the material composition quality. The line of Case B shown best line answers, which means, reduced amplitude in comparison to the Case A.

On the deflection graphs of Case B are observed straight proportionality between those measurements from a point on the sleeper or from a point at the middle of two sleepers. These results are also close to the same value.

Concerned to Case $\mathrm{B}$ in Fig. 5, when the locomotive axle groups are equidistant from the studied section occur minimum strain on the middle space of the sleeper, which could be reported as a value of $20 \%$ of the maximum measured ones. Concerned to Case $A$ in Fig. 5, the strain measurements at point 5 showed a difference of $30 \%$ between the load of first and third axles of the same locomotive group of axles because the support of the sleeper under it was inoperative, i.e., this sleeper was rotten and did not achieve to support the rail.

\section{Stresses Evaluation}

Other relevant feature that influences on the quality line of both lines, in terms of bearing capacity, is the use of crushed stone to ballast composition. Table 3 shows maximum strain for both two cases, permitting to analyze focusing its limit values.

The calculated values of stresses were obtained from the measured strains multiplied to an adopted value of elasticity modulus (E), the known Young's Modulus, under elasticity theory model, shown at Eq. (1) [8]. The values obtained are shown in Table 4.

$$
\sigma=E \cdot \varepsilon
$$

where,

$\sigma$. rail stress as function of measured deflection;

$E$ : rail elasticity modulus (Young's Modulus), $E=$ $205.000 \mathrm{~N} / \mathrm{mm}^{2}\left(2.050 .000 \mathrm{kgf} / \mathrm{cm}^{2}\right)$;

$\varepsilon$. elastic deflection (elastic strain) of rail or track caused by the load pattern (according to the used locomotive).

The maximum calculated stresses are 128.13 $\mathrm{N} / \mathrm{mm}^{2}\left(1,281 \mathrm{kgf} / \mathrm{cm}^{2}\right)$ at Gauge 5 of Case A and $38.95 \mathrm{~N} / \mathrm{mm}^{2}\left(389 \mathrm{kgf} / \mathrm{cm}^{2}\right)$ at Gauge 3 of Case B, among values of Table 4 . These values were calculated

Table 3 Maximum deflection values for each studied case (Case A and Case B).

\begin{tabular}{lllllll}
\hline & Strain 0 & Strain 1 & Strain 2 & Strain 3 & Strain 4 & Strain 5 \\
\hline Case A & $215 \times 10^{-6}$ & $390 \times 10^{-6}$ & $290 \times 10^{-6}$ & $545 \times 10^{-6}$ & $385 \times 10^{-6}$ & $625 \times 10^{-6}$ \\
Case B & $117 \times 10^{-6}$ & $150 \times 10^{-6}$ & $117 \times 10^{-6}$ & $190 \times 10^{-6}$ & $153 \times 10^{-6}$ & $185 \times 10^{-6}$ \\
\hline
\end{tabular}

Table 4 Maximum stresses to Case $A$ and Case $B$.

\begin{tabular}{llcccrrr}
\hline & Units & $\sigma_{0}$ & $\sigma_{1}$ & $\sigma_{2}$ & $\sigma_{3}$ & \multicolumn{1}{c}{$\sigma_{4}$} & \multicolumn{1}{c}{$\sigma_{5}$} \\
\hline \multirow{2}{*}{ Case A } & $\mathrm{N} / \mathrm{mm}^{2}$ & 44.08 & 79.95 & 59.45 & 111.73 & 78.93 & 128.13 \\
& $\mathrm{kgf} / \mathrm{cm}^{2}$ & 440.75 & 799.5 & 594.5 & $1,117.25$ & 789.25 & $1,281.25$ \\
\hline \multirow{2}{*}{ Case B } & $\mathrm{N} / \mathrm{mm}^{2}$ & 23.99 & 30.75 & 23.99 & 38.95 & 31.37 & 37.93 \\
& $\mathrm{kgf} / \mathrm{cm}^{2}$ & 239.85 & 307.5 & 239.85 & 389.5 & 313.65 & 379.25 \\
\hline
\end{tabular}


by Eq. (1), according to the adopted elastic deflection. The graph of Fig. 2 shows how the deflections recover, typical in an elastic medium.

The comparison of these two critical stresses permit to analyze the risk of overburden any studied railway part. The quotient of these two values, Case A maximum stress by Case B maximum stress equals to $128.13 / 38.95=3.28$, which means a surcharge of more than three times of stress at rails of Case A than rails of Case B. This relationship of stresses indicates a critical state of use which will reduce dramatically the rail lifetime.

The Case A and Case B data were loaded to Ferrovia 1.0 software, a FEM (finite element model) program developed for analysis in ballast on railways. The main features of locomotive and each studied railway part were considered than the sleeper spacing. In this case, it was considered double spacing.

The railway ballast coefficient, its elasticity modulus, was estimated under retro-analysis, considering track-ballast measurement deflections shown in Fig. 2. So, ballast elasticity, $E_{L}=240$ $\mathrm{N} / \mathrm{mm}^{2}\left(2,400 \mathrm{kgf} / \mathrm{cm}^{2}\right)$ and platform elasticity, $E_{P}=$ $60 \mathrm{~N} / \mathrm{mm}^{2}\left(600 \mathrm{kgf} / \mathrm{cm}^{2}\right)$. Table 5 presents results from Ferrovia 1.0 and stresses related to Young's Modulus, permitting comparisons.

In Table 5, it is possible to calculate the difference between stresses values from Ferrovia 1.0 and stress values from measured deflections. For Case B, stresses developed on the base rail and to the support point (on the sleeper), the difference between stress by software application and stress proportional to deflection, is $(34.3-31.40) / 31.4=0.09$, approximately $10 \%$. Nevertheless, this studied point, is the main to study shear efforts not flexural stresses. For Case A, stresses developed on the base rail and to the mid-span position, the difference between stress by software application and stress proportional to deflection, is $(59.0-44.1) / 59.0=0.25$, approximately $25 \%$. So, these levels of errors can be admitted as acceptable ones. Otherwise, for Case B, stresses developed on the head of rail and to the support point (on the sleeper),

Table 5 Base rail and top head rail stresses (Case A and Case B).

\begin{tabular}{|c|c|c|c|c|c|c|c|c|}
\hline \multirow[t]{2}{*}{ Case } & \multirow[t]{2}{*}{ Measurement position } & \multirow[t]{2}{*}{ Units } & \multirow[t]{2}{*}{ Force moment } & \multirow[t]{2}{*}{ Units } & \multicolumn{2}{|c|}{$\begin{array}{l}\text { Calculated stress: } \\
\text { Ferrovia } 1.0\end{array}$} & \multirow{2}{*}{$\begin{array}{l}\text { Measured stress } \\
\text { (Young's } \\
\text { Modulus) } \\
\text { Head }\end{array}$} & \multirow{2}{*}{$\begin{array}{l}\text { Measured stress } \\
\text { (Young's } \\
\text { Modulus) } \\
\text { Base (foot) }\end{array}$} \\
\hline & & & & & Head & Base (foot) & & \\
\hline \multirow{4}{*}{ A } & \multirow[t]{2}{*}{ On the sleeper } & $\mathrm{N} \cdot \mathrm{m}$ & 2507679 & $\mathrm{~N} / \mathrm{mm}^{2}$ & 75.0 & 55.3 & 128.1 & 78.9 \\
\hline & & $\mathrm{kgf} \cdot \mathrm{cm}$ & 255708 & $\mathrm{kgf} / \mathrm{cm}^{2}$ & 750.2 & 553.3 & $1,281.25$ & 789.25 \\
\hline & \multirow{2}{*}{$\begin{array}{l}\text { Middle of sleeper } \\
\text { spacing }\end{array}$} & $\mathrm{N} \cdot \mathrm{m}$ & 2671825 & $\mathrm{~N} / \mathrm{mm}^{2}$ & 79.9 & 59.0 & 80.0 & 44.1 \\
\hline & & $\mathrm{kgf} \cdot \mathrm{cm}$ & 272446 & $\mathrm{kgf} / \mathrm{cm}^{2}$ & 799.3 & 589.6 & 799.5 & 440.75 \\
\hline \multirow{4}{*}{ B } & \multirow{2}{*}{ On the sleeper } & $\mathrm{N} \cdot \mathrm{m}$ & 1927528 & $\mathrm{~N} / \mathrm{mm}^{2}$ & 46.6 & 34.3 & 39.0 & 31.4 \\
\hline & & $\mathrm{kgf} \cdot \mathrm{cm}$ & 196550 & $\mathrm{kgf} / \mathrm{cm}^{2}$ & 466.4 & 342.8 & 389.5 & 313.65 \\
\hline & \multirow{2}{*}{$\begin{array}{l}\text { Middle of sleeper } \\
\text { spacing }\end{array}$} & $\mathrm{N} \cdot \mathrm{m}$ & 1874620 & $\mathrm{~N} / \mathrm{mm}^{2}$ & 56.1 & 41.4 & 30.8 & 24.0 \\
\hline & & $\mathrm{kgf} \cdot \mathrm{cm}$ & 191155 & $\mathrm{kgf} / \mathrm{cm}^{2}$ & 560.8 & 413.6 & 307.5 & 239.85 \\
\hline
\end{tabular}

Table 6 Differences of base rail and top head rail stresses (Case A and Case B).

\begin{tabular}{|c|c|c|c|c|c|c|}
\hline \multirow{2}{*}{ Case } & \multirow{2}{*}{$\begin{array}{l}\text { Measurement } \\
\text { position }\end{array}$} & \multirow{2}{*}{ Units } & \multicolumn{2}{|c|}{ Calculated stress: (Ferrovia 1.0 software) } & \multirow{2}{*}{$\begin{array}{l}\text { Measured stress } \\
\text { (Young's } \\
\text { Modulus) } \\
\text { Head }\end{array}$} & \multirow{2}{*}{$\begin{array}{l}\text { Measured stress } \\
\text { (Young's } \\
\text { Modulus) } \\
\text { Base (foot) }\end{array}$} \\
\hline & & & Head & Base (foot) & & \\
\hline \multirow[b]{2}{*}{ A } & On the sleeper & $\mathrm{N} / \mathrm{mm}^{2}$ & $(75.0-128.1) / 128.1=0.41$ & $(55.3-78.9) / 78.9=-0.30$ & 128.1 & 78.9 \\
\hline & $\begin{array}{l}\text { Middle of sleeper } \\
\text { spacing }\end{array}$ & $\mathrm{N} / \mathrm{mm}^{2}$ & $(79.9-80) / 80=-0.01$ & $(59.0-44.1) / 44.1=0.34$ & 80.0 & 44.1 \\
\hline \multirow[b]{2}{*}{ B } & On the sleeper & $\mathrm{N} / \mathrm{mm}^{2}$ & $(46.6-39) / 39=0.19$ & $(34.3-31.4) / 31.4=0.09$ & 39.0 & 31.4 \\
\hline & $\begin{array}{l}\text { Middle of sleeper } \\
\text { spacing }\end{array}$ & $\mathrm{N} / \mathrm{mm}^{2}$ & $(56.1-30.8) / 30.8=0.82$ & $(41.4-24) / 24=0.73$ & 30.8 & 24.0 \\
\hline
\end{tabular}


the difference between stress by software application and stress proportional to deflection, is (128.1 $75) / 128.1=0.42$, approximately $42 \%$. For Case B, stresses developed on the head of rail and to the mid-span, the difference between stress by software application and stress proportional to deflection, is $(56.1-30.8) / 30.8=0.82$, approximately $82 \%$. These values are excessive high that were not envisaged in the Ferrovia 1.0 software. Table 6 shows errors of all calculated and measured stresses.

\section{Conclusions}

The behavior of ballast at the studied non tamped railway parts was equivalent to a fluid (Case A). The sleeper showed significant vertical displacement and torsion effort. Unexpected stress peak was observed on their rails, which could accelerate the rail lifetime if this condition would be constantly repeated, as successive cycles. The ballast densification is an unknown effect, in relation of the layers and soil features. The wide sleeper displacement practically prohibited any laser measurement. As the laser was stick on a reference beam and its bulkhead positioned on the sleeper, any significant vibration could damage the data quality.

The peak stresses occurrence probably is an effect of the uneven line, caused by sleepers under hypothesis of displacement. A new research is needed, because, in this work, it was just adopted double spacing sleepers to balance this problem.
The Case A measurements can be used as a model to analyze other Brazilian railways that show high level of rotten and missed sleepers among good ones.

In this paper, the amount of in situ measurements under true greatness and the comparison of two models of railway evaluation associated to a specific FEM software permitted to conclude that the traditional theoretical approach show good consistency to the studied cases.

\section{References}

[1] Informações Técnicas das Loconotivas C.V.R.D.-Acervo Técnico, Companhia Vale do Rio Doce, 2002.

[2] C. Esweld, Modern Railway Track, 2nd ed., MRT Productions, Zaltbommel, 2001.

[3] C.E.L. Paiva, C.F. Peixoto, L.F.M. Correia, P.R. Aguiar, Evaluation between two Brazilian railway tracks, Journal of Civil Engineering and Architecture 5 (46) (2011) 772-778.

[4] F.O. Rives, A.L. Pita, M.J.M. Puente, Treaty of Railroad-Track Way, Rueda S.L., Madrid, 1977.

[5] K. Hoffmann, An Introduction to Measurements Using Strain Gages, 1st ed., Hottinger Baldwin Messtechnik GmbH, Darmastadt, 1989.

[6] National Instruments, LabView User Manual, National Instruments Corporation, Austin, Texas, 2003.

[7] C.E.L. Paiva, L.C. Almeida, J.L.A.O. Sousa, Evaluation of strains in railways on ballast from data collected in the field, in: Proceedings 53rd Brazilian Congress of Concrete, Florianópolis, 2011.

[8] S.P. Timoshenko, Strength of Materials, Trad. José Rodrigues de Carvalho, Ed. USP, São Paulo, 1978. 